\title{
Mining co-operatives: A model to establish a network for sustainability
}

\author{
Wellington Alves*, Paula Ferreira, Madalena Araújo \\ ALGORITMI Research Centre, University of Minho, School of Engineering, Campus de Azurém, Guimarães, Portugal
}

\section{A R T I C L E I N F O}

\section{Keywords:}

Mining cooperatives

Sustainability

Brazil

\begin{abstract}
A B S T R A C T
Mining Co-operatives wield significant influence over the mining sector. These organizations have been getting increasing importance to support diggers through initiatives and policies to improve small-scale mining activ-ities. In spite of the importance of cooperatives to the local communities, studies on their role and contribution towards sustainable business practices in the sector are still scarce. This paper investigates the scenario of mining Cooperatives in Brazil through a set of interviews to the managers of these Co-operatives, which allowed to conclude on the relevance of the sector to establish a sustainable network into the mining sector in the country. The results indicated some key concerns related to lack of awareness towards cooperative principles and en- vironmental impacts and the reduced engagement with local community. The need to improve knowledge and academic background of both diggers and managers emerged as a major challenge to be overcome to ensure that cooperative principles are effectively put in place and guide the cooperatives towards sustainable development
\end{abstract}

\section{Introduction}

According to the International Co-operative Alliance (ICA) (2015), cooperativism has been well covered in sectors such as agriculture; credit; health and consumption. However, an overview of literature has shown this business model has not been fully explored in the mining sector. Yet, mining cooperatives have been getting increasing importance as powerful actors to support diggers (small artisanal miners) activities and to develop initiatives and policies to guide small-scale mining activities towards sustainability. In spite of the relevance of cooperatives to the small mining activities and also to local communities, related scientific literature concerning their organization, benefits and barriers is still scarce.

The case of Latin America is particularly relevant with studies showing that small-scale and informal mining is a major issue in the region, which gave rise to severe mining management problems, social conflicts and environmental pollution. The promotion of associations and cooperatives schemes proved to be an effective way to proceed with the formalization of these activities, to reduce environmental impacts and reduce social conflicts (ELLA - Evidence \& Lessons from Latin Ametica, 2012; Intergovernmental Forum on Mining, Minerals, Metals \& Sustainable Development (IGF), 2017; IMF - International Monetary Fund, 2017; Dorner, Franken, Liedtke, \& Sievers, 2012).

The creation of mining cooperatives presumes the alliance between individual interests, in order to achieve collective benefits for all the ones involved in the activity. As such, the alliance into cooperatives can be a key element to improve sustainability in the mining sector.

The objective of this research is to contribute to the debate of the interlinkage between sustainability and the cooperatives business models, assessing how the cooperatives can contribute to sustainable development and these sustainability objectives are embedded in sustainability practices. Bearing in mind these objectives, we examined the particular case of mining cooperatives in Brazil, which was the Latin American country with the highest number of operators in the artisanal and small mining sector in 2014 (based on data from Intergovernmental Forum on Mining, Minerals, Metals \& Sustainable Development (IGF), 2017).

In summary, the research aims to provide new insights on how this cooperative business model, can be used to build a network for sustainability in the mining sector, which should reflect not only the alliance nature of the cooperativism but also the well-established triplebottom-line principles. As such it should contribute to guide mining towards environmental and social good practices and ensure value creation to internal stakeholders and community.

The work was supported by an initial review of studies on the topic of mining cooperatives and its relation to sustainable development goals. The aim was not to be exhaustive, but rather to present a broad overview of the impacts related to mining exploitation and to assess how these aspects are considered in the case of small companies and cooperatives. A set of keywords were used for this revision, namely cooperatives; mining cooperatives; sustainable mining, to search for relevant references from the main data bases (Scopus, Science Direct,

\footnotetext{
* Corresponding author at: Departamento de Produção e Sistemas, Universidade do Minho, Campus de Azurém, 4800-058, Guimarães, Portugal.

E-mail addresses: wellingtonbn@gmail.com (W. Alves), paulaf@dps.uminho.pt (P. Ferreira), mmaraujo@dps.uminho.pt (M. Araújo).
} 
ICA - International Cooperative Alliance) focusing both peer-reviewed papers and reports from recognized international organizations.

The remainder of this paper consists in 6 sections as follows. Section 2 begins with a literature review on sustainable mining addressing in particular the role of cooperatives. Section 3 outlines the research methods and context focusing on the Brazilian case. The results are described in Section 4 and discussed in Section 5. Section 6 presents the main conclusions and points direction to future work.

\section{Literature review}

Sustainability has been considered as one of the most powerful principles of modern society. Over the past years the society is increasingly placing a value on sustainable technologies, processes and products that either have zero impact on our ecosystem, or function within the limits of its carrying capacity, also the society is increasingly sensitive to issues related to sustainable values (Vivoda \& Kemp, 2019).

Mining industry has been critical to many developing countries, particularly in South America. This sector has contributed significantly to socio-economic development through revenue generation, employment creation, and an increase in foreign direct investment. The impact of mining in developing countries is well researched and documented in (2018)

studies such Hilson (2002) and Pactwa, Woźniak, and Strempski,

Over the past decades, the mineral exploitation has experienced significant growth, contributing to economic development in many countries, especially the developing ones, given to the promises to generate wealth and jobs. This growth embraces mining activities in several sustainability concerns. These concerns may include not only environmental impacts such as atmospheric and water pollution, greenhouse emission through land degradation and deforestation, but also social issues which include high social costs, such as loss of regional culture, noise, health impacts, conflicts over land use, loss in the air quality, among other.

Countries such as Australia, Bolivia and Eastern Democratic Republic of Congo have begun to address the social and environmental impacts of mining cooperatives aiming to achieve sustainability (IMF International Monetary Fund, 2017). At the forefront, as a pioneer steppingstone within sustainability scope, the Bruntland Report developed under World Commission on Environmental and Development (World Commission on Environment \& Development. WCED, 1987), defines sustainable development as capacity of current generations to meet their needs without compromising the capacity of achieving the same by future generations. Given these concerns about future generations and the underlying activities of the mining sector that require depletion of raw materials resources, the concept of sustainability in the mining sector is not fully consensual. Mining activities frequently involve destruction of rich mining areas giving rise to several environmental and social costs, not only locally, but also globally which impact upon many stakeholders. Notwithstanding this, the literature already identifies sustainable practices and different strategies already applied in the mining sector or which could be adopted by mining companies towards sustainability.

The report from the Australian Government (2011), supports that there is no unique definition of sustainability for the mining industry, but highlights some of the key aspects that should be considered, namely the need to embrace social, environment and economic pillars, the requirement for offsetting the negative impact and/or reinvestment benefits to reach economic growth and social justice. Laurence (2011a) reviews also the concept of sustainability in mining and concludes on the need to go beyond the traditional visions mainly focusing on successful economic, environmental and community outcomes. The author argues then on the need to include two additional aspects, namely the consideration for safety issues, in particular in what concerns mine accidents, and the efficient management and extraction of the resources for optimal site extraction for a long-term horizon of the mine operation.

According to Pactwa et al. (2018), in order to contribute to sustainable development, the mine is obliged to minimize the impact on the environment during the entire life cycle, from the extraction to closure. The Agenda for Sustainable Development 2030, proposed 17 Objectives of Sustainable Development and 169 associated tasks, which are the continuation of the Millennium Development Goals. The function of these objectives and tasks is to stimulate activities in areas such as mining which has key significance for humanity and for the planet.

To guide mining companies towards achieving sustainability, many strategies have been suggested in the literature. Mining companies frequently target sustainability by two main avenues, firstly by addressing environmental practices; secondly, by holding benefits to society beyond the sites where resources are extracted, through com-

pensating or reinvesting the benefits for the depletion of mineral resources. By implementing sustainable practices to mitigate impacts from current activities and bringing together society and environment, the mining sector can benefit societies and contribute to sustainable

outcomes, resulting in socio-economic development that should go beyond the sites of resource extraction (Wessel, 2016; Moran \& Kunz, 2014). Some examples of these sustainable practices include the efforts towards waste management (Macías, Pérez-López, Caraballo, Cánovas, \& Nieto, 2017; Clyde, Champagne, Jamieson, Gorman, \& Sourial, 2016; Wagner \& Raymond, 2015), schemes for benefit sharing with communities (Admiraal, Sequeira, McHenry, \& Doepel, 2017; Söderholm \&

Svahn, 2015) or the efforts towards conservation of non-renewable resources applying circular economy concepts (Lèbre, Corder, \& Golev, 2017).

With regard to sustainability assessment methodologies in the mining sector, these are mainly based on the identification and evaluation of criteria that expose potential impacts on the three dimensions of sustainable development: social, economic and environmental (Organisation for Economic Cooperation \& Development - OECD, 2008). These criteria are operationalized as indicators, which can be quantified and integrated in some coherent framework or decision support tool. Marnika, Christodoulou, and Xenidis, (2015), for example, proposed a set of indicators for sustainable mining operation in protected areas and included them in a decision support tool, which allowed to assess alternative mining processing scenarios. Another example from Sinan Erzurumlu and Erzurumlu (2015), highlighted the importance of local communities and propose participatory approach a multi-criteria decision analysis to assess sustainability of mining projects.

These adverse impacts of mining activities may be present in all business scale, whether large or small mining companies. On regards to the impacts related to small mining activities, these ones are not strongly debated in the current literature, especially impacts of activities from mining cooperatives, which may be considered important players in the small mining activities. There has been no significant debate about the role of mining cooperatives for sustainable development, which, in a few developing countries, such as Brazil, play a key role in this sector. As Milanez and Puppim de Oliveira (2013) highlighted, there is a growing demand for the development of more sustainable practices within artisanal and small-scale mining frequently organized as cooperatives. Only a few countries where mineral cooperatives play an important role have been developing policies to mitigate their social and environmental impacts as well as supporting mineral cooperatives to operate in a sustainable way (Bocangel, 2001; de Haan \& Geenen, 2016; Duff et al., 2009).

\subsection{The importance of mining co-operatives business models}

One important factor, which has been taken into account in the current literature, is the discussion about the major problems and socioeconomic benefits originated by Small-Medium and Artisanal (SMA) mining companies to a number of developing countries. In many parts 
of the world, small-scale mining activities are at least as important as large-scale mining activities with an important role in poverty alleviation and rural development.

Notwithstanding the local importance of SMAs from the mining sector, they are mostly known for their high environmental costs and poor health and safety record, as well as less profitable and fundamentally unsustainable activity (Hentschel, Hruschka, \& Priester, 2002). However, SMAs have an important role on the economic growthas well as on the development of local communities where these busi- nesses are located. Following these lines many studies such as Tschakert(2009); Langston et al. (2015); Canavesio (2014), Hilson (2012), Kotilainen, Prokhorova, Sairinen, and Tiainen, (2015); Majer (2013); Oramah, Richards, Summers, Garvin, and McGee, (2015); Seccatore, deTomi, and Veiga, (2014), have been discussing the contribution of small-scale companies to the stakeholders of the mining sector ad- dressing the substantial investments provided by these companies in remote regions.

According to Alves, Ferreira, and Araujo, (2016) the main barriers faced by SMAs from mining sector are related to three key aspects, community engagement, lack of technology and lack of environmental practices. A range of challenges such as a disorganized and unsupported industrial sector and poor conditions to operate is also associated to these companies.

A particular case of these small-scale companies are the mining cooperatives, being them defined as an organization composed by individuals or even a group of business owned and operated for benefits of its members. Cooperatives and mutual enterprises (CMEs) are then organizations in which buyers or suppliers are also the owners, shareholders and members of a community of purpose (Mamouni, Mazzarol, Soutar, \& Siddique, 2018). Dunn (1988) initially discussed the main idea behind a cooperative; the author argued that the creation of a cooperative should allow joining mutual efforts collectively, in order to achieve an objective that otherwise would be unobtainable. This search for collective welling and inter-support is an essential point that distinguish cooperative organizations from other business models

As a business model, cooperatives are often formed in response to a problem in the market, usually due to imbalance of power between a supplier of goods and the customer (International Co-operative Alliance (ICA), 2017; Reynolds, 2013). These enterprises can adopt a range of different forms in several countries (Mazzarol, Limnios, \& Reboud, 2013) and are able to operate in many different fields, from agricultural and mining activities to tourism and health.

The Co-operatives represent a mean to maintain the independence of organizations in different sectors. At the same time, these organizations provide the means for small enterprises to become competitive in the market. Additionally, Co-operative business models also provide individuals the opportunity to become owners and core decision-makers of the organization, as opposed to being forced into becoming employees. For small organizations its provides smallholders with the opportunity to improve their level of productivity and increasing their share of income from what it would be under traditional organizational forms (Altman, 2015) and to gain access to resources that will enhance their organizational development (Mazzarol, Limnios, \& Reboud, 2013).

To address concerns about well-being for people, cooperatives have emerged as an alternative showing that people working together, may achieve more benefits, and overcome barriers than working individually. The cooperatives model raised in XIX century after the Industrial Revolution in England, aiming to support workers that had been suffering with severe labour exploitation. Since then, the Co-operative movement has been increased, extending across the globe and embracing different sector of economy in several countries (Organaziation of Brazilian Co-operative - OCB, 2016).

Over the past decades, the cooperative model has been growing and being adopted by several economic sectors around the world. Nowadays, cooperatives are represented worldwide by the
International Co-operatives Alliance (ICA), which is a global voice and forum for knowledge, supporting cooperatives in many countries. According to International Co-operatives Alliance, co-operatives are defined as an autonomous association of persons united voluntarily to meet their common economic, social, and cultural needs and aspirations, through a jointly-owned and democratically-controlled enterprise (Dale et al., 2013). The importance of the cooperatives model has experienced a significant growth since its introduction in 1844 . Nowadays the sector is estimated to have around 1 billion members and employs directly or indirectly, 250 million people around the world (International Co-operative Alliance (ICA), 2017).

Studies such as Esnard, Lyne, \& Old, 2017 and Dilger, Konter, \& Voigt, 2017 show some of the key advantages of the Co-operatives business models to local economic growth. These organizations can support players by improving their negotiating power reducing unit transport, processing, and transaction costs while better meeting their common needs. Moreover it contribute to better institutional arrangements, making it easier for the cooperatives to operate legally and build relationships with players and public organizations (Esnard et al., 2017). The Co-operative approach is not about boosting the investors' return on investment, but on providing members/owners the conditionsto be part of the market (Dilger et al., 2017).

Most of contributions of co-operatives are related to preoccupation with local issues, since their basic concerns the support for regional development (Osti, 2012). Cooperatives have also been demonstrated resilience in the face of economic crises; the survey developed by International Co-operative Alliance (ICA) (2011) showed positive evidences on this from cooperatives business model. For instance, in the early 2000's these enterprises have grown continuously across sectors during the economic crisis (Birchall \& Ketilson, 2009). Also Carini and Carpita (2014), analyzed Italian Co-operatives that operated in the industrial and supports service sector and concluded on the resilience of Co-operatives in times of economic crisis with more stable employment levels than corporations.

Nonetheless, is important to note that despite of benefits of co-operatives, they have also been facing challenges, namely inadequate environmental for cooperative development, lack of specific laws and regulations, absence of a co-operative legal framework, limited engagement in articulating a global vision, lack of engagement with research institutions and lack of engagement with members (International Labour Organization, 2015; Zamagni \& Zamagni, 2010). This last aspect is particularly relevant, with studies such as Bhuyan (2007) arguing on the need to acknowledge the members need and ensure their active participation, for the long run survival of the co-operatives.

\subsection{Co-operative principles and sustainability}

The most important aspect of co-operative is the focus on the collective needs instead of on the individual ones (Organaziation of Brazilian Co-operative - OCB, 2016b). At the basis of cooperatives, operations are supposed to guarantee to the associated people, increased income, throughout mutual help, democracy, equality and responsibility. This collective basis can support co-operatives to achieve sustainability and embed economic, environmental and social concerns on their decision and activities.

The Co-operatives, values and principles enshrined in the ICA Statement have shaped the identity of Co-operatives and have become the yardstick by which to assess public and private measures related to Co-operatives over the past 120 years (Henrÿ, 2013). Fig. 1 illustrates the seven cooperatives principles which guide their activities.

There is a strong relationship between the seven co-operatives principles and sustainability. A report developed by the International Labour Organization (International Labour Organization, 2015), has launched an initiative on the potential contribution of cooperatives and their principles to sustainable development. The study acknowledged the role of co-operatives in contributing to economic development, 


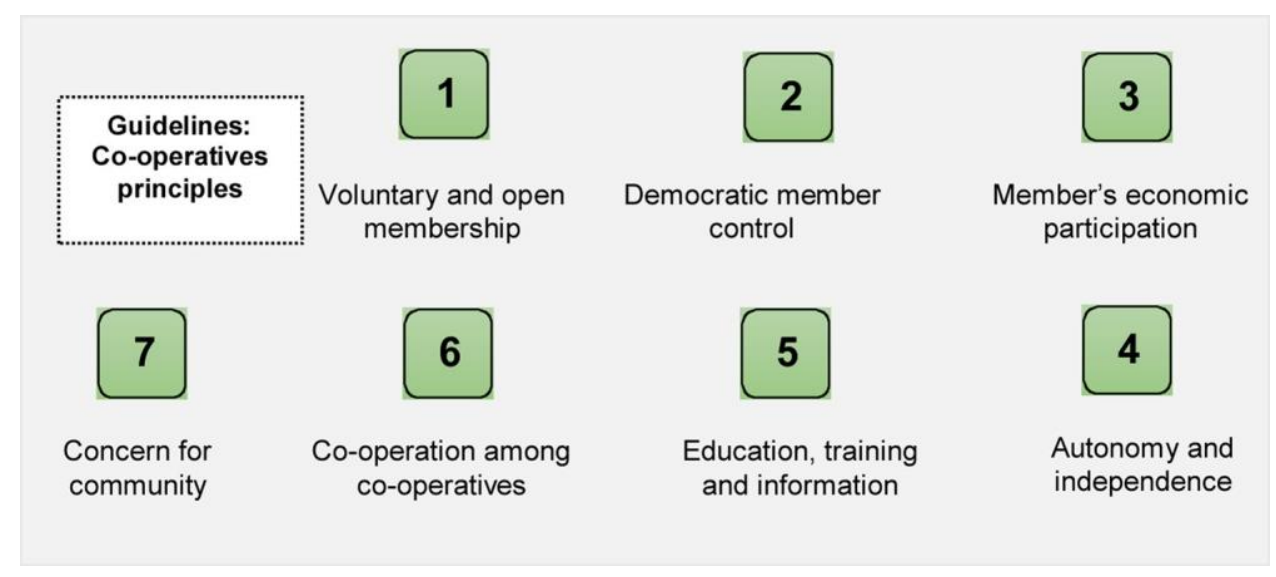

Fig. 1. Co-operatives principles (ICA, 2016).

social inclusion and poverty reduction, particularly in developing countries. The report highlighted the strong link between co-operatives principles and the social dimension of sustainability, given to the principles established for this business models have most potential to contribute to create jobs, ending poverty, sustainable livelihoods, and equitable growth.

When followed, the implementation of those seven principles by cooperatives will enable attaining different outcomes, improving the communities' social and economic development, which are sustainability pillars. This view strengthens the idea that co-operatives should be a driver to sustainability when their principles are implemented and developed. According to International Labour Organization (2013) since cooperatives are organizations driven by principles and valuebased they can be considered as a sustainable and participatory form of business and have been identified by United Nations as a way forward to the Sustainable Development Goals (SDGs).

As outlined previously, as social and economic organizations, cooperatives are inserted into the dynamics of society, requiring them to be able to attend social interests. Many benefits can be attributed to the creation of cooperatives which may be linked to the sustainabilitytriplebottom-line principles:

- On regards to social issues, poverty reduction and social exclusion are some of the reasons that may be considered (Grigore, 2013) and which are clearly related to the fifth and seventh co-operative principles;

- On regards to economic aspects, sharing economic profits (third cooperatives principle), mutual autonomy between workers in enterprises (fourth co-operative principle), equitable access to goods and services, represent economic benefits created through cooperatives. These principles, altogether, contribute to economic development of the community, which is directly related to the seventh cooperative principle (concern for the community). Co-operatives, have then an important role to play in the reconfiguration of the economy as a whole as well creating alternative forms of governance (Cheney, Santa Cruz, Peredo, \& Nazareno, 2014).

- In what concerns environmental aspects, co-operatives have already demonstrated the capacity to develop initiatives for a sustainable management of natural resources in particular at local scale. For instance, in India and Africa cooperatives are increasingly initiatives on facilitating clean water to remote regions (International Labour Organization, 2013). Also, energy co-operatives have been contributing to achieve sustainable energy goals of energy access, contributing to energy efficiency and reduced emissions. In UK, US and Karnakata (India) co-operatives have been also identified as leading enterprises on adopting renewable energy such as solar and wind power to rural populations (International Labour Organization, 2015). Even at a global level, Baranchenko and
Oglethorpe (2012) analysed the specific case of agriculture cooperatives and concluded that these businesses can drive efficiencies within food supply chains and open routes for technological changes required to reduce GHG emissions.

According to The World Cooperative monitor, the world's top 300 co-operatives jointly have an estimated global turnover of 2.2 trillion USD, which is equivalent to the GDP of Brazil (International Co-operative Alliance (ICA) (2015)). It is clear that activities from cooperatives have been providing jobs, services and infrastructure demanded by the society, covering different sectors of the economy, once showing that cooperatives can play a role on the fostering sustainable development.

\subsection{The role of mining co-operatives}

Mining co-operatives are defined as associations created by miners that aim to support the exploitation, industrialization and commercialization of mining products. These organizations also seek to contribute for encouraging small-mining producers, through humans and ethics values, to promote social inclusion, better miners' income distribution and poverty reduction (Freitas, Freitas, \& Macedo, 2015; Rodrigues \& da, 2008).

The majority of small mining-activities are performed by diggers which face several barriers and difficulties when they work individually, including difficulties on obtaining working license, lack of occupational health and safety conditions to work in mines and difficulties to sell raw materials for a fair and profitable price. The mining co-operatives can then have a positive impact to diggers, namely in supporting them through social and economic benefits. For instance, the creation of cooperatives through small producers has been devel- oping alliances between mining companies supplying their products and creating benefits to both, communities and companies (Grätz, 2009). Mining co-operatives can then assist developing countries not only in the economic field, but in threefold: creating jobs, developing strategic networks between small producers and enterprises and also increasing social development.

Among the many economic sectors where co-operatives are operating, the mining sector needs special attention. On one hand they can support diggers by organizing their activities, and giving them the opportunity to be part of the mineral market and, on the other hand, the community benefits can be enhanced, which is particularly relevant, given the key role of this activity to environmental and social wellbeing of local populations. Mining co-operatives have an important repercussion in local scale and could be key actors in extractive industries, providing a vital role to many communities in the economic field (Helwege, 2015). This raises questions with regards to how successfully can the market barriers be surpassed when diggers are 


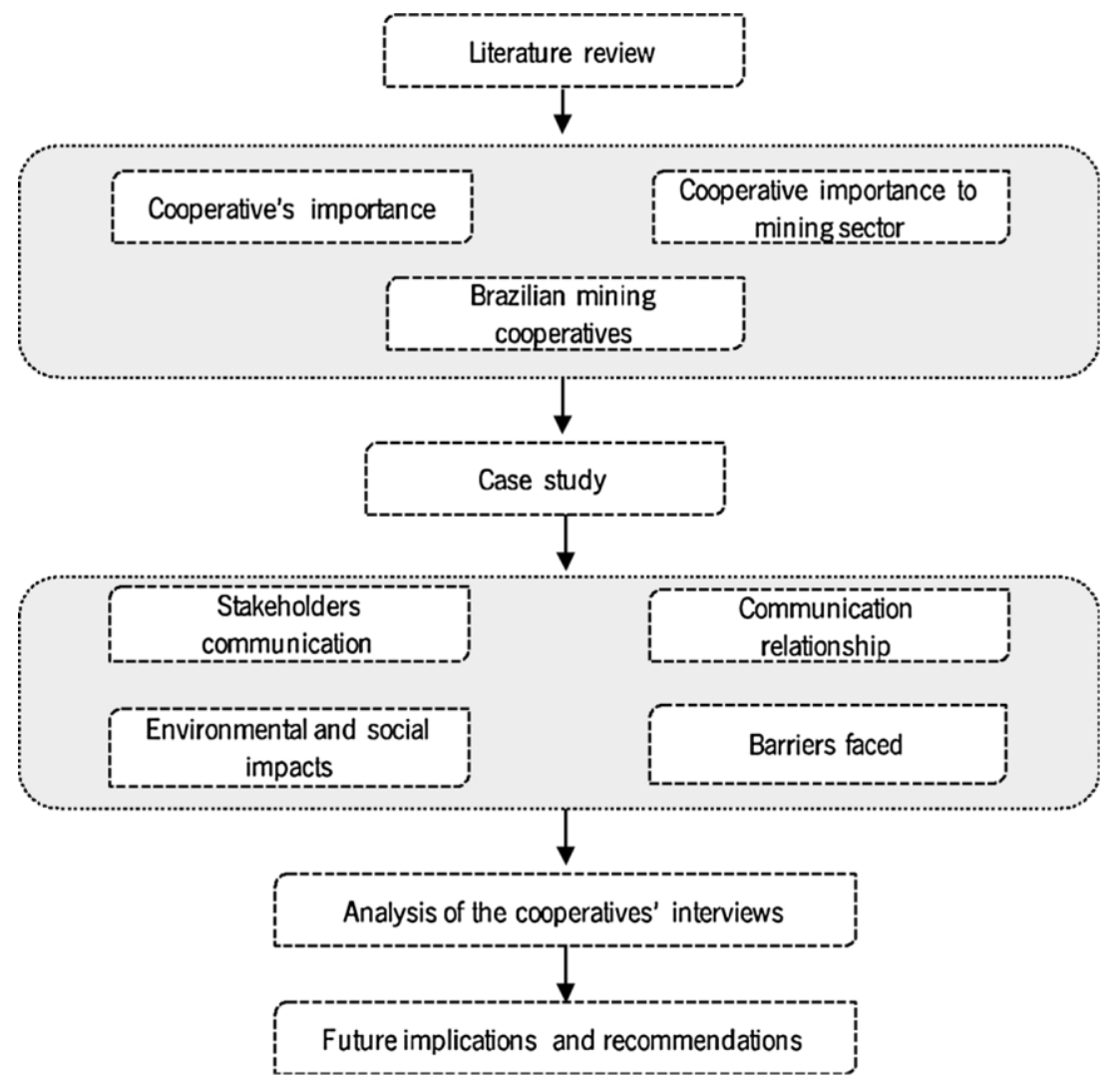

Fig. 2. Research methodology.

integrated into mining cooperatives and how this inclusion can enhance social inclusion.

In spite of the key role of mining co-operatives, the debate about them is still limited. This paper intends to contribute for further discussion, widening the debates by combining two main objectives driving the creation of mining co-operatives. Firstly, the socio-economic benefits to diggers derived from the legal formalization of the diggers' work, supporting them and the surrounding counterparts. Secondly, the discussion of the role of mining co-operatives as a sustainable network within the mining sector.

\section{Context and methods}

In this research, a qualitative approach was adopted in order to achieve the objective proposed. The research was designed in order to obtain information about the importance of mineral co-operatives to Brazilian mining sector as well as, their contribution to the overall sustainable benefits and barriers faced by those cooperatives. Therefore, the research design was developed having a case study as strategy, and using a qualitative and quantitative method approach (mix-method), as summarized in the methodology described in Fig. 2.

In terms of research strategies, case studies are commonly used by researches focused on an empirical investigation of a particular con-

temporary phenomenon within its real-life context, using multiple sources of evidence. A case study strategy has also considerable ability to generate a better understanding about a phenomenon (Mark, Philip, \& Adrian, 2009).

The combination of cases studies and qualitative interviews to study the artisanal small-scale miners is proved to be a successful approach given the related social concerns which are difficult to capture in general statistical data which are frequently scarce and with a low re- solution. A recent study from Yakovleva and Vazquez-Brust (2018) addressed the informal miners across different governance levels in the mining sector in Ghana through interviews with different stakeholders including the small-scale miners. Interviews were also used by Smith, Smith, John, and Teschner, (2017) to examine the perspectives of artisanal and small-scale miners on an initiative to formalize the sector in a rural region in Guianas. Also, Weng et al. (2015) addressed small- scale mineral extraction in East Cameroon using an approach based onthe selection of a set of companies used as case studies and interviews with the main decision makers.

Following these past examples, a case study research strategy was chosen in this work. Interviews and secondary data obtained by literature review and archival data analysis were used as data collection techniques.

In order to gather reliable case evidence, the analysis of data was based on data triangulation. According to May (2002), this method is adopted within mainstream qualitative research for dealing with different sources of data. This method is also adequate for studies where qualitative data are collected using semi-structured interviews (Saunders, Lewis, \& Thornhill, 2009). This method was chosen due to the variety of data sources (May (2002) and Saunders et al. (2009))), which includes: 1) secondary materials, such as literature about cooperatives business models, reports, books and websites; 2) reports from public mining agencies in Brazil and Paraíba state; (3) field observations, such as co-operatives visits; 4 ) informal conversation, such as communicating with cooperatives members. These approaches were able to enrich the data analysis as well as increasing the reliability of the case study.

Based on the limited scientific literature available concerning mining co-operatives and on the empirical study developed, the final step described the main findings about specific Brazilian state mining cooperatives and draws expectations on wider Brazilian mining cooperatives view on the matter. Findings were analyzed according to the specific aspects as described in the results and discussion sections. 


\subsection{The Brazilian context}

Brazil is a large, unevenly developed country with different co-op-

erative traditions and historically mineral exploitation, which has contributed to the formation of the national territory. Nowadays, in digging' activities (garimpos, performed by diggers - garimpeiros) the status of cooperation with adoption of collective actions still persists, in spite of the effectiveness of this cooperation being difficult to achieve (Freitas et al., 2015). Meanwhile, the legal formalization of the ex-istence of small-mineral producers and diggers is a big challenge facedby the Brazilian mining sector. The majority of "garimpeiros" work il- legally, and mineral cooperatives pose as an alternative instrument to support them towards legal formalization, training, and also con- tributing increase their productivity.

In Brazil, following the general perception worldwide, mining cooperatives are intricately linked to negative aspects such as failure experiences and unsustainable and disorganized activities. However, they can be considered a prominent opportunity to integrate diggers into formal associations, helping them to develop their activities supported by a legal entity or organization. The co-operatives in Brazil have been a relevant instrument in many contexts such as encouraging frontier development by smaller producers, encouraging market production, enhancing technological development and improving economies of scale (Freitas et al., 2015; Stattman \& Mol, 2014).

Assuming minerals co-operatives as a driver to overcome challenges posed to individual diggers, the Brazilian government regulated and agreed on the creation of mineral cooperatives to operate in areas of 501000 ha. This regulation has been encouraging small mining pro- ducers to take part of co-operatives, claiming the importance of orga- nization to increase the performance of small-mining activities (Organaziation of Brazilian Co-operative - OCB, 2016b).

Mining co-operatives have been contributing to Brazilian economy in large extent through creation of jobs. In 2015, the total number of people working (associated and employees) on mining cooperatives accounted to 961,541 , representing nearly $2 \%$ of the overall Brazilian mining sector (Organaziation of Brazilian Co-operative - OCB, 2016b, 2016a). Although this number is low comparatively to other mining organizations, their contribution is particularly meaningful to fiscal revenue of municipalities where they are located and to local development of those frequently poor and depressed regions.

\subsection{Methods}

In order to capture the importance of mineral co-operatives to the mining sector, this research began with a comprehensive literature review identifying potential studies which could support a better understanding about mineral cooperatives. However, after searching numerous journals associated with this topic, few works were found, demonstrating lack of research in this field, or a gap in the literature. From the information found, this step described the importance of cooperatives to the mining sector followed by the actual scenario of Brazilian mining co-operatives as described in previous sections.

A case study was adopted as research strategy aiming to study within its contextual scenario, the specific phenomenon of the mineral co-operatives in Brazil. This research focused on the state of Paraiba in Brazil, chosen due to its natural characteristics and the willingness to cooperate in the research. Paraiba has seven mining co-operatives operating, all of them were invited to take part in this research and five accepted.

The sample consists of five mining co-operatives which agreed to participate in the study. The characterization covers the profile of the respondents, the minerals exploited and some quantitative information on the cooperative's operation. Table 1 shows a sum up of the cooperatives technical record.

Table 2 indicates the distance between the co-operatives included in
Table 1

Technical record of participating co-operatives.

Geographical area Paraíba state - Brazil

this research and the nearest community, demonstrating that this 
Co-operativities size: Small- mining activities

\begin{tabular}{llll}
\hline & $\begin{array}{l}\text { Operation } \\
\text { (years) }\end{array}$ & Cooperatives members & Mineral exploited \\
\hline Co-operative A & 9 & 19 & Feldspar-Mica \\
Co-operative B & 7 & 108 & Quartzite \\
Co-operative C & 9 & 13 & Feldspar-Mica \\
Co-operative D & 5 & 30 & Kaolin-Mica \\
Co-operative E & 8 & 178 & Quartzite-Kaolin \\
& $\bar{X}=7,6$ & $\bar{X}=699$ & \\
\hline
\end{tabular}

Table 2

Distance of mining co-operatives and community. (Source: estimated from field research (2016)).

Distance from nearest community $(\mathrm{km})$

$\begin{array}{ll}\text { Co-operative A } & 6 \\ \text { Co-operative B } & 2 \\ \text { Co-operative C } & 3 \\ \text { Co-operative D } & 10 \\ \text { Co-operative E } & 6 \\ & \bar{X}=5,4\end{array}$

distance is less than $10 \mathrm{~km}$ for all of them and as such its local community impacts are likely to be relevant.

The Paraiba state is located in the northeast region of Brazil. This region is known as Borborema Pegmatite region, due to the important repository of minerals as feldspar, mica, quartzite and kaolin as well asthe high quality of those minerals.

Due to the importance of Paraiba state with regards to minerals exploited there, also as the role of cooperatives in the exploitation of these minerals, the five co-operatives were chosen to be part of this research as case studies.

In-depth semi-structured interviews were devised to address sustainability in the co-operatives, covering social, economic and environmental concerns. As such, the interviews were focused on four specific aspects namely:

(1) general information about the co-operatives, including years of operations, existence of license to operate, sector of operation namely metallic or non-metallic and type of mineral extracted;

(2) characterization of the interviewee, including educational background, years working at the company, work position and link to other organization (e.g. universities, associations or NGOs);

(3) co-operatives and stakeholder's communication, addressing aspects such as sustainability report issuing, barriers faced to sustainability reporting and existence of mechanisms to communicate sustain- ability;

(4) relationship between the co-operative and community, addressing aspects such as recognition of importance of local community in- volvement in the decision-making process, developed actions to promote involvement, possible disturbance generated by the com- pany during the mineral extraction and reported by the community, and the use of Social License; and

(5) environmental and social impacts, including perception of the company about its impacts on the regions where it is located, willingness of the company to make changes towards minimization of negative impacts, incentives required by the company to reduce the negative impacts, developed actions toward minimization of 
environmental impacts, barriers faced to obtain the environmental license and developing projects to environmental recovery.

The entire data collection lasted for three months (August to November) of the year 2016, in five different cities where the co-operatives are located in the Paraíba state in Brazil, namely Nova Palmeira, Várzea, Pedra Lavrada, Frei Martinho and Junco do Seridó. The interviews were held face to face with the president and/or manager or their representative of the co-operatives, ${ }^{1}$ they took place in each one of the co-operatives and lasted approximately 40-80 minutes each interview. All the interviews were digitally recorded in order to facilitate the data analysis.

The profile of the interviewees consists in educational background, work experience at the co-operative and interviewees' relationship with relevant associations such as university, trade unions, public organizations among others. The profile of the interviewees is presented in Table 3.

The interviews carried out were used as the main data collection approach, supplemented by field observations, and a picture of this set of mineral cooperatives was detailed demonstrating the importance of those cooperatives to the economic and social development of the local communities in the Paraiba state. Furthermore, the main operating barriers faced by the mineral co-operatives were also identified and described.

\section{Results and analysis}

Result analysis followed the main issues previously outlined in the literature review, the identified gaps have then prompted the main topics that have served as basis to develop the interviews and established the following path for the presentation of the key findings: (1) Cooperative's profile; (2) Co-operative's principles; (3) Community relationship and social impacts and (4) Environmental impacts.

\subsection{The co-operatives' profile}

All co-operatives consulted in this research work with the non-metallic sector. According to National Department of Research Mineral (DNPM), the mineral production in Brazil account for a total of 72 minerals substances, including 23 metallic, 45 non-metallic and 4 energetics.

In 2015, the non-metallic sector represented a total of $2.53 \%$ of the Brazilian industrial GDP (National Department of Research Mineral DNPM, 2016). In the non-metallic sector, minerals such as kaolin, quartzite, feldspar and ornamental rocks are particularly relevant to the Brazilian minerals reserves. For instance, Brazilian ornamental rocks represented in 2013 a total of $8.5 \%$ of the production traded in the international market and ranked the fifth place in the global market. The quartzite and feldspar are the main non-metallic minerals exploitedand the region addressed in this research, which is considered as a strategic geological province for these minerals and as such of strategic importance for the sector and for the economy of the country (Ministry of Mines \& Energy, 2017).

The participating co-operatives are operating according to the Brazilian legislation and also to the DNPM (National Department of Research Mineral) rules, which regulates mining activities, in this case small-mining activities (areas 50-1000 ha). An interesting character-istic of the participating co-operatives is that they are relatively young enterprises (<10 years), which explains some of the challenges they face as well as the still timid contribution they have to the Brazilian mining sector. Mining co-operatives located in Paraiba state have

1 Although the interviews carried out focused on management board or presidents of cooperatives, in some cases, as in cooperatives E and D, some cooperatives members participated once they were asked to participate. provided job opportunities for local communities contributing to economic diversification and social inclusion. However, the rudimentary methods still used by mining co-operatives have also created a series of social and environmental impacts to the region which were addressed in the interviews.

In what concern the interviewees, results showed that most of them had a low education profile on the specific topic of mining as well as low formal education and are working for the cooperative for at least 5 years. The majority of them are in the co-operatives since its estab- lishment, and according to them, the investment in training by co- operatives, is still scarce or does not exist. Moreover, the participation of the interviewed in other organizations such as, universities or trade unions is limited, with only two of them collaborating with in a uni- versity and a trade union.

\subsection{Co-operatives principles}

Table 4 summarizes the co-operatives principles followed by the set of participating co-operatives, according to nomenclature presented in Fig. 1. The main objective was to assess if the interviewees recognize the basic principles of co-operatives, and how these principles are effectively considered in the creation and operation of these co-operatives.

As shown in Table 1, cooperatives B and E are the only ones linked to some other organization i.e. universities and/or trade unions. Additionally, co-operatives $\mathrm{B}$ and $\mathrm{E}$ have also been identified as those following more set of co-operatives principles. These results may be related to the size of the companies as these two, are the only ones which surpass 100 members. In fact, the results demonstrated that mostof the interviewed were not aware of the co-operative principles and most cooperatives do not operate according to these principles. From the analysis, the following aspects can be highlighted:

- Principle 1 states that co-operatives should be voluntary and open to all people able to use the co-operative and participate on it. This principle represents the basic premise for the co-operatives included in the research and seems then to be well established and understood by all co-operative members and managers.

- Principle 2 states that co-operatives should be democratic organizations controlled by their members. The co-operatives consulted argue that all cooperative members have voting right, but few of them apply it to management appointment or to have an activity role on setting new policies and making decisions. This can be explained by the generalized lack of skills in the mining fields and lack of formal education for the majority of co-operatives members.

- Principle 3 states that benefits to members are in proportion with the transactions established by the co-operative. Meaning that the economic benefits shared between co-operatives members depends on the amount of minerals exploited by diggers and traded through the co-operatives. However, most of the cooperatives consulted agreed that the majority of diggers are not aware about this principle and prefer to sell the minerals in the black market due to the facility to receive the payment in cash and avoiding fees and taxes. Is should be underlined that the economic benefits of the co-operative are also important to generate royalties to the municipality and as such, the completion of this principle is of fundamental importance for local economic development.

- Principle 4 states that cooperatives are autonomous organizations and controlled by their members, where the agreement with other organizations such as governments and private companies is allowed but has to ensure the democratic control. The participating cooperatives argued that governmental support is required due to their lack of economic sources, but they are aware that this lead to interferences and jeopardize the cooperative autonomy. In addition, they agreed that as is the case detailed under principle 2, decisions are taken by few members and not all co-operative members are 
Table 3

Profile of the respondents $(n=5)$.

\begin{tabular}{|c|c|c|c|c|}
\hline & Present position at cooperative & Years of work at cooperative & Educational background & Associated with some organization \\
\hline Co-operative A & President & 9 & $\mathrm{~N} / \mathrm{Ba}$ & No \\
\hline Co-operative B & President representative & 4 & Mining technical & Yes \\
\hline Co-operative $\mathrm{C}$ & Management board member & 6 & $\mathrm{~N} / \mathrm{B}$ & No \\
\hline Co-operative D & President & 5 & $\mathrm{~N} / \mathrm{B}$ & No \\
\hline \multirow[t]{2}{*}{ Co-operative E } & Management board member & 5 & $\mathrm{~N} / \mathrm{B}$ & Yes \\
\hline & & $\bar{X}=5,8$ & & \\
\hline
\end{tabular}

a No background, meaning no formal educational.

Table 4

Co-operatives principles used.

\begin{tabular}{llllllll}
\hline \multicolumn{7}{c}{ Cooperatives principles } \\
\cline { 2 - 7 } & 1 & 2 & 3 & 4 & 5 & 6 & 7 \\
\hline Co-operative A & $\checkmark$ & & & & $\checkmark$ & \\
Co-operative B & $\checkmark$ & $\checkmark$ & & & $\checkmark$ \\
Co-operative C & $\checkmark$ & $\checkmark$ & $\checkmark$ & $\checkmark$ & $\checkmark$ \\
Co-operative D & $\checkmark$ & & & & & \\
Co-operative E & $\checkmark$ & $\checkmark$ & & & $\checkmark$ & $\checkmark$ & $\checkmark$ \\
\hline
\end{tabular}

1-Voluntary and open membership 2- Democratic member control 3- Member economic participation 4- Autonomy and independence 5- Education, training and information and independence 6- Co-operation among Co-operatives 7Concern for community.

aware about the consequences and responsibilities of the decisions taken.

- Principle 5 underlines of the importance of education, training and information to employees, representatives and managers of co-operatives towards an effective contribution to the co-operative development. This principle is directly concerned with the management of the co-operatives, but most of participating co-operatives argued that members are not aware about this principle and its importance. They also argued that training programs for co-operatives members are still scarce.

- Principle 6 reinforces the strengthening of the co-operative movement when co-operatives work together. However, results showed that only two out of the five co-operatives consulted have been developing business partnership. The interviewees argued that the lack of trust, collaboration and communication between cooperatives are recurrent problems that turn more difficult the cooperation. The effective implementation of this principle could bring considerable returns and respond to some of the identified challenges. For instance, some interviewees reported the need to access to specific machines to mineral processing which are available in other cooperatives who are close to them and do not use it regularly, but the lack of cooperation prevents this sharing agreements.

- Principle 7, the last cooperative principle underlines the concern for the community through the development of policies toward sustainable development envisaging social welfare of local population. This principle represents the role of the co-operatives on local development, but only few participating co-operatives are aware of the principle, and implement strategies for community engagement and increase social acceptability of the sector.

In summary, the interviewees revealed low awareness towards cooperatives principles and no formal procedures are implemented to ensure that the creation and management of co-operatives will follow these principles. This particularly remarkable, as the linkage between co-operatives principles and sustainability goals is evident in what concerns economic, social and environmental development raising concerns on the effectiveness of co-operatives, at their present state, to establish a truly network for sustainability.

\subsection{Community relationship and social impacts}

As outlined before, one of the motives to create mining cooperatives is to establish a better organizational structure for diggers. In terms of economic benefits through improvement of organizational structure to diggers, the price of minerals (tons) traded by co-operatives can be considered as an example of the benefits estimated to be achieved through the mineral prices traded when diggers are working into cooperatives. For instance, for minerals such as Feldspar, Quartzite; Mica and Kaolin when traded by cooperatives the value is, respectively, about $39 \%, 34 \%, 59 \%$ and $99 \%$ higher than the value traded in the blackmarket (values estimated from field research). However, field research revealed that some members of the cooperatives still traded the mineral in the black-market, in spite of lower prices, which sev- erally undermines the public and municipal revenues.

Co-operatives are directly linked to local communities; these activities often involve families living close to these premises. In addition, mines are frequently located in remote geographic areas with limited infrastructures, thus the improvement of social inclusion through the emergence of social infrastructures represents a key outcome of cooperatives' activities.

In what concerns community relationship, three aspects were addressed during the interviews concerning namely the recognition of the importance assigned to local community involvement, the existence of actions to promote communities' involvement and recognition of reported disturbance. Results also revealed that most cooperatives agreed that is important their involvement with local community, as well as promoting actions to this purpose.

Notwithstanding the interviewees recognition of the importance of involvement with the local community, when asked about the community engagement into co-operatives' activities, the majority of them indicated that the co-operative have not developed practical actions to pursue that engagement. Some of the interviewees argued that, the nearest community have not reported any disturbance. However, during the field research and through direct contact with a few local-cooperatives' members (diggers) complain on negative aspects such as noise, dust and some health problems were registered.

Examples of actions targeting the minimization of negative impacts and compensations measures were also addressed during the interview. For instance, support to schools at local community, development of health and safety strategies and establishment of professional training courses were given as possible examples of possible actions. However, the interviewees argued that neither of these actions are developed by the cooperatives; they claimed that it is difficult for cooperatives to make these efforts, due to both the lack of resources and to the orga- nization culture itself.

Another topic pointed out during the interviews related to the community was the existence of Social Licence (SL). Over the past decade this SL concept has become embedded and accepted within the core mining industry as an attribute of success to community engagement. The SL is supported on the locally-impacted communities' perception of value towards company's activities. The interviewees were 
asked about the SL existence or if they had some information about SL meaning. In spite of the importance of SL to ensure and demonstrate community engagement, all participating cooperatives reported that SL was not implemented. Moreover, they were not aware of its meaning and importance.

\subsection{Environmental impacts}

Despite of the development of policies towards social and economic issues in the mining sector, the environmental impacts generated by mining activities are still the major threat and concern. On regarding to mining co-operatives, although undertaking small-scale activities, environmental impacts still persist directly related to water, air and land use. Environmental issues include dust emission, noise, land occupation, energy and water use, the latter ones being intensively used in mining activities.

To address environmental issues the interviews aimed at understanding three main aspects linked to environmental impacts originated by those cooperatives. More specifically, (1) co-operatives' perception about their impacts, (2) actions developed by co-operatives towards environmental impact reduction and (3) key players able to support cooperatives in environmental concerns.

The results show that environmental impacts remain an extremely complex and frequently overlooked issue for mining co-operatives. Table 5 presents results concerning the interviewees' perceptions about the impacts generated by cooperatives' activities. For the majority of them these activities only have positive impacts, more precisely only social benefits such as jobs creation and wage growth. As such, environmental issues are not perceived, or at least considered by the interviewees.

Table 6 presents a set of actions towards minimization of environmental impacts, obtained from the literature review. Interviewees were asked about its implementation on their own organization but most of them admitted that none of these actions or just few of them were in place.

Most of co-operatives argued that it is difficult to develop some of these actions, due to their lack of skills and monetary support. Even recycling, resource reduction and water consumption reduction during processing, which were actions implemented already by some of largest co-operatives, were assumed as difficult to be put in practice.

Table 7 shows that monetary, governmental, administrative support schemes which the interviewees claimed to be essential for environmental performance improvement. Amongst those, the need for specialized staff was indicated as a major requirement for reducing negative environmental impacts and even to comply with the legal requisite of environmental recovery after mining closure.

According to the interviewees, the monetary support could help them to hire specialized staff to work on the management of the cooperatives as well as to develop environmental actions. Governmental support is foreseen as a compliance facilitating strategy. The participating co-operatives do not have environmental license to operate, and this support could help them to achieve this license and avoid fines. It was also argued that they have several difficulties such as lack of information about the license and delays in the public administration process for obtaining this license, thus seen as an important problem to

Table 5

Perceptions of co-operative's impacts.

Impact's perception Positive Negative Both c

\begin{tabular}{lllll}
\hline Co-operative A & Yes & $\checkmark$ & \\
Co-operative B & No & & \\
Co-operative C & Yes & $\checkmark$ & $\checkmark$ & $\checkmark$ \\
Co-operative D & Yes & $\checkmark$ & \\
Co-operative E & No & & \\
\hline
\end{tabular}

c Impacts are positive and negative. be overcome.

\section{Discussion}

The research conducted, has allowed for the suggestion of important contributions and scientific implications, in what concerns the relevance of cooperatives in the mining sector to achieve sustainability. This research offers insights to the current literature on sustainability status of the Brazilian mining sector and contributes towards existing knowledge by improving expertise in the fields of the relations to local communities and environmental impacts. Following these findings, recommendations can then be derived which should be useful for both companies and researchers in the field of social innovation models for the mining and industrial sector.

Based on the results of the interviews, field research and literature review, Table 8 summarizes a few examples of problems that Brazilian SMAs tend to face and the possible contribution of the co-operative approach to solve them. Recommendations are then proposed for key actions to be considered to promote the effective engagement of these companies with sustainable principles described by the Sustainable Development Goals (SDG) designed for the mining sector (Columbia Center on Sustainable Investment, 2016).

Mining co-operatives have an important repercussion in local scale and could be key actors in extractive industries, providing a vital role to many communities in the economic field. This raises questions with regards to how successfully can the barriers be surpassed when diggers are integrated into mining cooperatives and how this inclusion can enhance social inclusion.

As demonstrated in the literature review, co-operative activities can bring both economic and social benefits. The results of our research show that the participating co-operatives were aware of these benefits. However, the severe environmental impacts related to land use, dust emission, and large amount of energy and water required for mining activities, seem to be ignored by the interviewees. These results corroborate the idea that negative concerns and in particular environmental issues remain poorly addressed in these mining cooperatives, which tend to value mainly social and economic benefits. Moreover, even when those social concerns are acknowledged, the practical implementation of measures to benefit communities is still extremely scarce.

The use of co-operatives principles aiming for a collective work can bring important benefits to co-operative members through the improvement of their skills, offering technical assistance and training. It is also important to highlight that in line with National Department of Research Mineral - DNPM (2016) lack of knowledge in mining fields and specialized staffs are important challenges to be overcome bysmallmining activities. In fact, most of the identified key actions are somehow related to the low academic background of the members of the cooperatives and the need to increase knowledge through training activities directed towards diggers and managers. Moreover, as Massaro and de Theije (2018) highlighted the social participation and partnerships among government, universities and local co-operatives are important factors for the development of this sector, which is still far from being achieved for this group of co-operatives.

Finally, it is worth mentioning the generalized reduced awareness of the co-operatives principles as most members tend to see themselves more as employees than as members of the co-operatives. In fact, this lack of engagement with and perceived relevance of some of the principles was already discussed in other sectors and countries (see for

example Oczkowski, Krivokapic-Skoko, and Plummer, (2013)) and some authors argue that the values of new co-operators are changing and individuality gains seem to prevail over communality (Puusa, Hokkila, \& Varis, 2016).

In particular, studies such as Mazzarol, Limnios, \& Reboud (2013) underline the importance of membership identity and loyalty as fundamental aspects for the cooperative survival and growth. This does not 


\begin{tabular}{lll} 
ACTIONS & & \\
\hline Recycling & $\begin{array}{l}\text { Resources } \\
\text { reduction }\end{array}$ & $\begin{array}{l}\text { Water consumption } \\
\text { (reduction) }\end{array}$
\end{tabular}

Liquids effluents
(minimization)

Renewable energy sources

(use)
Energy efficiency (mechanisms available)

Co-operative A
Co-operative B $\checkmark$
Coo-perative C

Table 7

Required support to impacts' reduction.

\begin{tabular}{|c|c|c|c|c|}
\hline \multicolumn{5}{|l|}{ Support } \\
\hline & Monetary & Specialized staff & Governmental & Administrative \\
\hline Co-operative A & $\checkmark$ & & $\checkmark$ & \\
\hline Co-operative $\mathrm{B}$ & & $\checkmark$ & & $\checkmark$ \\
\hline Co-operative $\mathrm{C}$ & $\checkmark$ & & $\checkmark$ & \\
\hline Co-operative D & $\checkmark$ & $\checkmark$ & & $\checkmark$ \\
\hline Co-operative E & $\checkmark$ & & & \\
\hline
\end{tabular}

mean that the principles should be overlooked, but rather demonstrates the need to adapt the organization format to the sector and to community context and to improve and adjust communication that should be well targeted to both internal and external stakeholders.

\section{Conclusions}

In this research, sustainability in mining co-operatives was discussed along its three dimensions namely, social, economic and environmental, while taking into account the importance of these co-operatives to the Brazilian mining sector. An empirical study was conducted addressing in particular the case of non-metallic mining cooperatives in the Paraiba state, Brazil. The possible benefits of the cooperatives activities were summarized and its contribution towards sustainability was analysed. Furthermore, the main barriers to ensure sustainable practices in cooperatives were pointed out.

The research was based on a review of the limited available literature concerning mineral c-ooperatives and, due to the newness of this topic (sustainability concerns) to mining co-operatives, the research attempted to empirically analyse data collected from a set of Brazilian mineral cooperatives. Moreover, the study allowed to propose a research approach supported on interviews which, although being focused on the mining sector, can be easily adapted to different sectors to understand how the co-operative principles are acknowledged and considered in practice. Additionally, it can be understood if and how cooperatives can effectively contribute to deal with sustainability challenges in particular in what concerns the social dimension and local population concerns. As such, the practical implications of the study are particularly relevant for the mining sector but the scientific usefulness of the research methodology can go much beyond one specific sector allowing to assess the relevance of the cooperatives business model to reach effective networks for sustainability

\subsection{Co-operative challenges and barriers}

Co-operatives have been important instruments in twofold: to support diggers on improving their activities and to support small-mining activities to overcome their major challenge, namely their legal formalization.

The co-operatives that participated in this research are relatively young; all of them have ten years of operation or less. It is one of the reasons argued by some of them for facing several barriers, either to operate or to understand the importance of sustainability.

In line with previous studies published by the Organization of Brazilian Co-operatives - $\mathrm{OCB}$, the empirical findings of this research identified a list of problems faced by the participating cooperatives, namely: (1) difficulties to follow the co-operatives principles; (2) reduced understanding of cooperatives principles by all (as some of the members see the cooperatives as an employer company and expect regular wages and do not understand sharing of profits concept); (3) difficulties on the legal formalization of the business activities at the Public Administration Institutions; (4) lack of skills to manage the cooperative; (5) reduced governmental support; (6) shortage of working capital and (7) lack of training of specialized staff.

Activities of co-operatives should take into account the seven cooperatives principles. However, these principles seem to constitute challenges to the co-operatives included in this research, since some of these principals are ignored. In fact, the interviews with the five participating co-operatives provided indications that only one of the seven co-operatives principles is being followed by all of them, namely the one concerning voluntary and open membership. Four other principles related to required education, training and information and independence, cooperation among Co-operatives and concern for community were followed by two out of the five cooperatives; these had support in training by a public organization, namely a university.

For the rest of the participating co-operatives that do not adequately consider the principles, it could be justified by their members' lack of formal educational and lack of information about the principles meaning. The investment in formal educational and information to cooperatives members could facilitate a better understanding about the importance of using the principles towards sustainable development of the co-operative as well as benefits to the members.

The use of the co-operatives principles represents the key aspects ruling this business model; when properly considered they can support attaining sustainability objectives within mining activities. Notwithstanding, findings in this research indicate that the participating co-operatives are not working in line with all those principles, and have several difficulties to put them into practice which rises concerns on their effective response to collective needs and contribution towards sustainable development at local and global levels.

The results indicate that in the long term, to overcome these barriers an important first step for co-operatives would be to get support to operate more efficiently in what concerns the use of both natural and human resources. It is worth mentioning, that as cooperatives push into remote geographical areas, depending on the raw materials availability, they are also changing the lives of those people living there.

\subsection{Sustainability in the mining co-operatives}

To address concerns about sustainability in mining co-operatives it is important that the companies are aware of the concept meaning and its dimensions. From the interviews results the majority of the participating co-operatives are not aware of the sustainability meaning, and 
only economic and social concerns are considered important to them, ignoring environmental issues.

The obtained results showed that initiatives for sustainability in mining co-operatives are still scarce in the Brazilian mining sector. Interviewees were asked about their understanding of the sustainability meaning and if it was considered in their activities; they were also asked about disclosure or mechanisms to report sustainability. All ar- gued that these issues are not taken into account; they even showed difficulties in understanding the sustainability meaning and its importance.

Strategies and actions towards sustainability need to be disseminated and integrated into the co-operatives business model in Brazil. Positive outcomes from the incorporation of sustainability concerns on mining co-operatives activities can be expected if adequately linking sustainability with economic benefits to co-operatives members, social development of the region and stakeholders as well as environmental impacts reduction.

\subsection{Wrap-up and future work}

This research's findings contribute to the literature related to the role of mining co-operatives in the Brazilian mining sector. Benefits and barriers faced by them were underlined and key actions to be undertaken were identified. Furthermore, this research provides additional discussion about the importance of co-operatives business model as an instrument to support small-mining activities, unveiling these issues mostly absent in the current literature.

Moreover, the proposed methodology based on a set of case studies and face-to-face interviews was proved to be a successful approach to improve scientific understanding of the social concerns related to the mining exploration, showing that, as Flyvbjerg (2006) highlighted, case study may be central to scientific development. The study showed the relevance of using a direct contact to stakeholders to understand their concerns and their difficulties to deal with the formalization processes.

As outlined, co-operatives business model is based on a set of principles, most of them linked to sustainability principles. Assuming that co-operatives will be able to combine sustainability and co-operatives principles, they may contribute to overcome the current idea discussed in the literature that mining activities cannot be sustainable in the long term. As such, mining co-operatives should be seen as important entities to be part of a network to improve the sustainability of the mining sector and in particular increasing social welfare of local communities.

Regardless of these potential contributions, it becomes evident that, negative environmental impacts are still one of the major challenges to be overcome. The lack of knowledge associated with a low level of education from the co-operative coordinators, the perceived impunity for noncompliance with the environmental regulations and low development of local communities contribute to this environmental degradation of the sector.

The need to build a good relationship with communities and the environment has been realized in several countries where mining takes place. The seek for building this relation is posing a challenge to the Brazilian mining sector, even if not yet fully perceived; meanwhile, further discussions in this direction pose relevant field for future research. In particular, the issue of local communities' perception and acceptance must be further debated and studied as mining activities are still a main source of conflict. Future research should then address not only these perceptions but also strategies for local community engagement and building truly participatory decision-making processes in the cooperatives. Finally, new business models that can contribute to increase awareness towards environmental impacts and minimize these damages should be considered, including strategies embedding circular economy concepts at cooperative level. 


\section{Acknowledgments}

The authors would like to thank to CAPES and Science Without Borders scholarship, BEX Process 10.190-13-9 for providing financial support to this research.

\section{References}

Admiraal, R., Sequeira, A. R., McHenry, M. P., \& Doepel, D. (2017). Maximizing the impact of mining investment in water infrastructure for local communities. The Extractive Industries and Society, 4(2), 240-250. https:/ / doi.org/10.1016/j.exis.2017 01.014 .

Altman, M. (2015). Journal of Co-operative Organization and Management Cooperative organizations as an engine of equitable rural economic development. Biochemical Pharmacology, 3(1), 14-23. https:// doi.org/10.1016/i.jcom.2015.02.001.

Alves, W., Ferreira, P., \& Araujo, M. (2016). Sustainability in the Brazilian mining sector : Barriers and interventions to overcome. XXXVI Encontro Nacional de Engenharia de Producão.

Baranchenko, Y., \& Oglethorpe, D. (2012). The potential environmental benefits of $\mathrm{Co}-$ operative businesses within the climate change agenda. Business Strategy and the Environment, 21(3), 197-210. https://doi.org/10.1002/bse.733.

Bhuyan, S. (2007). The "people" factor in cooperatives: An analysis of members' attitudes and behavior. Canadian Journal of Agricultural Economics, 55(3), 275-298. https:// doi.org/10.1111/j.1744-7976.2007.00092.x.

Birchall, J., \& Ketilson, L. H. (2009). Resilience of the cooperative business model in times of crisis. Johnston Brichall Lou Hammond Ketilson http:/ / doi.org/Finance.

Bocangel, D. (2001). Small-scale mining in Bolivia: National study mining minerals and sustainable development. Mining, minerals and sustainable development, Vol. 71. Retrieved from http:// pubs.iied.org/pubs/pdfs/G00713.pdf.

Canavesio, R. (2014). Formal mining nvestments and artisanal mining in southern Madagascar: Effects of spontaneous reactions and adjustment policies on poverty alleviation. Land Use Policy, 36, 145-154.

Carini, C., \& Carpita, M. (2014). Journal of Co-operative Organization and Management the impact of the economic crisis on Italian cooperatives in the industrial sector. Biochemical Pharmacology, 2(1), 14-23. https://doi.org/10.1016/j.jcom.2014.03. 001.

Cheney, G., Santa Cruz, I., Peredo, A. M., \& Nazareno, E. (2014). Worker cooperatives as an organizational alternative: Challenges, achievements and promise in business governance and ownership. Organization, 21(5), 591-603. https://doi.org/10.1177/ 1350508414539784

Clyde, E. J., Champagne, P., Jamieson, H. E., Gorman, C., \& Sourial, J. (2016). The use of a passive treatment system for the mitigation of acid mine drainage at the Williams Brothers Mine (California): Pilot-scale study. Journal of Cleaner Production, 130, 116-125. https:/ / doi.org/10.1016/i.jclepro.2016.03.145.

Columbia Center on Sustainable Investment (2016). Mapping mining to the sustainable development goals: An atlas. Retrieved fromhttp://unsdsn.org/wp-content/uploads/ 2016/11/Mapping_Mining_SDGs_An_Atlas.pdf.

Dale, A., Duguid, F, Lamarca, M. G. Hough, P. Tyson, P. Foon, R, et al. (2013). Cooperatives and Sustainability: An investigation into the relationship. Co-operatives and Sustainability Report, 1-76.

de Haan, J., \& Geenen, S. (2016). Mining cooperatives in Eastern DRC the interplay between historical power relations and formal institutions. Extractive Industries and Society, 3(3), 823-831. https:// doi.org/10.1016/j.exis.2016.05.003.

Dilger, M. G., Konter, M., \& Voigt, K. (2017). Journal of Co-operative Organization and Management Introducing a Co-operative-specific business model : The poles of profit and community and their impact on organizational models of energy Co-operatives. Journal of Co-operative Organization and Management, 5(1), 28-38. https://doi.org/10. 1016/i.jcom.2017.03.002.

Dorner, U., Franken, G., Liedtke, M., \& Sievers, H. (2012). Artisanal and small-scale mining (ASM). Polinares. Retrieved fromhttp:/ / pratclif.com/2015/mines-ressources/ polinares/chapter7.pdf,

Duff, G., Garnett, D., Jacklyn, P., Landsberg, J., Ludwig, J., Morrison, J., et al. (2009). A collaborative design to adaptively manage for landscape sustainability in north Australia: lessons from a decade of cooperative research. Landscape Ecology, 24(8) 1135-1143. https:// doi.org/10.1007/s10980-008-9236-5.

Dunn, J. R. (1988). Basic cooperative principles and their relationship to selected practice. Journal of Agricultural Cooperatives, 3(7), 32-46. Retrieved from http:/ / purl. umn.edu/46430.

ELLA - Evidence and Lessons from Latin Ametica (2012). ). Small-scale and informal mining: A big problem for latin american states.

Esnard, R., Lyne, M., \& Old, K. (2017). Journal of Co-operative Organization and Management Factors a ff ecting the value added by agricultural cooperatives in Saint Lucia : An institutional analysis. Journal of Co-operative Organization and Management 5(December 2016), 73-79. https:// doi.org/10.1016/j.jcom.2017.10.003.

Flyvbjerg, B. (2006). Five misunderstandings about case-study research. Qualitative Inquiry, 12(2), 219-245. https:// doi.org/10.1177/1077800405284363.

Freitas, A. F., Freitas, A. F., \& Macedo, A. S. (2015). Cooperativismo Mineral: Da Indução De Uma Forma Organizacional Aos Desafios De Uma Organização Sustentável. Revista Brasileira de Gestão E Desenvolvimento Regional, 12(1), 107-131. Retrieved from http://rbgdr.net/revista/index.php/rbgdr/article/view/2123.

Grätz, T. (2009). Moralities, risk and rules in West African artisanal gold mining communities: A case study of Northern Benin. Resources Policy, 34(1-2), 12-17. https:// doi.org/10.1016/j.resourpol.2008.11.002.
Grigore, A.-A. (2013). Social economy entities: A worldwide overview. Review of Applied Socio-Economic Research, 6(2), 111-120 http:/ / doi.org/http:/ /www.reaser.eu/ Archive.php.

Helwege, A. (2015). Challenges with resolving mining conflicts in Latin America. Extractive Industries and Society, 2(1), 73-84. https:/ / doi.org/10.1016/j.exis.2014.10. 003.

Henrÿ, H. (2013). New opportunities for co-operatives: New opportunities for people. Journal of Co-Operative Organization and Management, 1(1), 47-48. https:/ / doi.org/ 10.1016/j.jcom.2013.06.001.

Hentschel, T., Hruschka, F., \& Priester, M. (2002). Global report on artisanal \& small-scale mining.

Hilson, G. (2002). Small-scale mining and its socio-economic impact in developing countries. Natural Resources Forum, 26i don(1), 3-13.

Hilson, G. (2012). Corporate Social Responsibility in the extractive industries: Experiences from developing countries. Resources Policy, 37(2), 131-137. http://doi. org/10.1016/j.resourpol.2012.01.002.

IMF - International Monetary Fund (2017). World economic outlook: Gaining momentum? World economic outlook April 2017. Retrieved fromwww.imfbookstore.org.

Intergovernmental Forum on Mining, Minerals, Metals and Sustainable Development (IGF) (2017). Global Trends in Artisanal and Small-Scale mining (ASM): A review of key numbers and issues. Retrieved fromhttp://www.iisd.org/sites/default/files/ publications/igf-asm-global-trends.pdf.

International Co-operative Alliance (ICA) (2011). Global 300 Report 2010: The world's major cooperatives and mutual businessesRetrieved from http://ica.coop/sites/default/ files/attachments/Global300 Report2011.pdf.

International Co-operative Alliance (ICA) (2015). Co-Operative Sector Announces Global Turnover of 2. 2 Trillion USD for Top 300 Co Ops, and Employment Figures of at Least 250 Million Worldwide. 32(2)3-4.

International Co-operative Alliance (ICA) (2017). Co-operative identity, values and principles. Retrieved fromhttp://2012.coop/en/what-co-op/Co-operative-identity-valuesprinciples.

International Labour Organization (2013). Cooperatives and the sustainable developmen goals. 2013. Retrieved fromhttp://www.ilo.org/wcmsp5/groups/public/-ed_emp/ documents/publication/wcms_240640.pdf.

International Labour Organization (2015). Cooperative movement development and the post2015 process: Survey findings. Retrieved fromhttp://www.ilo.org/wcmsp5/groups/ public/@ed_emp/documents/publication/wcms_248497.pdf.

Kotilainen, J., Prokhorova, E., Sairinen, R., \& Tiainen, H. (2015). Corporate social responsibility of mining companies in Kyrgyzstan and Tajikistan. Resources Policy, 45.

Langston, J. D., Lubis, M. I., Sayer, J. A., Margules, C., Boedhihartono, A. K., \& Dirks, P. H. G. M. (2015). Comparative development benefits from small and large scale mines in North Sulawesi, Indonesia. The Extractive Industries and Society, 2(3), 434-444. https:/ / doi.org/10.1016/j.exis.2015.02.007.

Laurence, D. (2011a). Establishing a sustainable mining operation: An overview. Journal of Cleaner Production, 19(2-3), 278-284. https://doi.org/10.1016/j.jclepro.2010.08. 019.

Lèbre, É., Corder, G., \& Golev, A. (2017). The role of the mining industry in a circular economy: A framework for resource management at the mine site level. Journal of Industrial Ecology, 21(3), 662-672. https://doi.org/10.1111/jiec.12596.

Macías, F., Pérez-López, R., Caraballo, M. A., Cánovas, C. R., \& Nieto, J. M. (2017) Management strategies and valorization for waste sludge from active treatment of extremely metal-polluted acid mine drainage: A contribution for sustainable mining. Journal of Cleaner Production, 141, 1057-1066. https://doi.org/10.1016/j.jclepro. 2016.09.181.

Majer, M. (2013). The practice of mining companies in building relationships with local communities in the context of CRS formula. Journal of Sustainable Mining, 12(3), 3847.

Mamouni, E., Mazzarol, T., Soutar, N., \& Siddique, K. H. (2018). The member wears four Hats : A member identi fi cation framework for co- operative enterprises. Journal of $\mathrm{Co}^{-}$ operative Organization and Management, 6(March), 20-33. https://doi.org/10. 1016/j.jcom.2018.03.003.

Mark, L., Philip, T., \& Adrian, S. (2009). Reseacrh methods for business students. Harlow: Pearson Education Limited.

Marnika, E., Christodoulou, E., \& Xenidis, A. (2015). Sustainable development indicators for mining sites in protected areas: Tool development, ranking and scoring of potential environmental impacts and assessment of management scenarios. Journal of Cleaner Production, 101, 59-70. https://doi.org/10.1016/j.jclepro.2015.03.098.

Massaro, L., \& de Theije, M. (2018). Understanding small-scale gold mining practices: An anthropological study on technological innovation in the Vale do Rio Peixoto (Mato Grosso, Brazil). Journal of Cleaner Production, 204, 618-635. https://doi.org/10. 1016/j.jclepro.2018.08.153.

May, T. (ed.) (2002). Qualitative Research in Action, 1. http:/ / doi.org/10.1017/ CBO9781107415324.004.

Mazzarol, T., Limnios, E. M., \& Reboud, S. (2013). Co-operatives as a strategic network of small firms: Case studies from Australian and French Co-operatives. Journal of $\mathrm{Co}^{-}$ operative Organization and Management, 1(1), 27-40. https://doi.org/10.1016/j.jcom. 2013.06.004.

Milanez, B., \& Puppim de Oliveira, J. A. (2013). Innovation for sustainable development in artisanal mining: Advances in a cluster of opal mining in Brazil. Resources Policy, 38(4), 427-434. https://doi.org/10.1016/j.resourpol.2013.07.003.

Ministry of Mines and Energy (2017). ANUÁRIO ESTATÍSTICO DO SETOR DE TRANSFORMAÇÃO DE NÃO METÁLICOS. Brasília. Retrieved fromhttp://www.mme. gov.br/web/guest/secretarias/geologia-mineracao-e-transformacao-mineral/ publicacoes.

Moran, C. J., \& Kunz, N. C. (2014). Sustainability as it pertains to minerals and energy supply and demand: A new interpretative perspective for assessing progress. Journal 
of Cleaner Production, 84, 16-26.

National Department of Research Mineral - DNPM (2016). Departamento Nacional de produção mineral. Anuário mineral brasileiro: Principais subsrâncias metálicas. Brasilia. Retrieved from http://www.dnpm.gov.br/dnpm/paginas/anuario-mineral/arquivos/ dnpm_amb_2016_metalicos.

Oczkowski, E., Krivokapic-Skoko, B., \& Plummer, K. (2013). The meaning, importance and practice of the co-operative principles: Qualitative evidence from the Australian co-operative sector. Journal of Co-Operative Organization and Management, 1(2), 5463. https:// doi.org/10.1016/j.jcom.2013.10.006.

Oramah, I. T., Richards, J. P., Summers, R., Garvin, T., \& McGee, T. (2015). Artisanal and small-scale mining in Nigeria: Experiences from Niger, Nasarawa and Plateau states. The Extractive Industries and Society, 2(4), 694-703. https:/ / doi.org/10.1016/j.exis. 2015.08.009.

Organaziation of Brazilian Co-operative - OCB (2016). Diagnóstico do Ramo Mineral Desafios para o Setor, 69. Retrieved fromOrganaziation of Brazilian Co-operative OCBhttp://www.ocb.org.br/site/agencia_noticias/noticias_detalhes.asp? CodNoticia $=19588$

Organaziation of Brazilian Co-operatives - OCB (2016). Panorama do cooperativismo brasileiro. Brasília: Organaziation of Brazilian Co-operative - OCB.

Organisation for Economic Cooperation and Development - OECD (2008). Conducting sustainability assessments. OECD Publishinghttps://doi.org/10.1787/ 9789264047266-en.

Osti, G. (2012). Green social cooperatives in Italy: A practical way to cover the three pillars of sustainability? Sustainability: Science, Practice and Policy, 8(1), 82-93. https:/ / doi.org/10.1080/15487733.2012.11908087.

Pactwa, K., Woźniak, J., \& Strempski, A. (2018). Sustainable mining - Challenge of Polish mines. Resources Policy, (September), 1-9. https://doi.org/10.1016/j.resourpol.2018. 09.009.

Puusa, A., Hokkila, K., \& Varis, A. (2016). Individuality vs. communality-A new dual role of co-operatives? Journal of Co-Operative Organization and Management, 4(1), 22-30. https:/ / doi.org/10.1016/j.jcom.2016.02.002.

Reynolds, B. A. (2013). Defining the value of the cooperative business model. 1-6. https:/ / doi.org/10.1002/tie.

Rodrigues, A. F., \& da, S. (2008). Cooperativismo Mineral no Brasil: O caminho das pedra passo a passo. Retrieved from131. http://www.dnpm.gov.br/dnpm/publicacoeseconomia-mineral/arquivos/bussola-mineral-o-cooperativismo-mineral-no-brasil.

Saunders, M., Lewis, P., \& Thornhill, A. (2009). Research methods for business students Vol. 5 .

Seccatore, J., de Tomi, G., \& Veiga, M. (2014). Efficiency as a road to sustainability in small scale mining. Materials Science Forum, 805, 395-402.

Sinan Erzurumlu, S., \& Erzurumlu, Y. O. (2015). Sustainable mining development with community using design thinking and multi-criteria decision analysis. Resources Policy, 46, 6-14. https://doi.org/10.1016/j.resourpol.2014.10.001.

Smith, N. M., Smith, J. M., John, Z. Q., \& Teschner, B. A. (2017). Promises and perceptions in the Guianas: The making of an artisanal and small-scale mining reserve. Resources Policy, 51(November), 49-56. https:/ / doi.org/10.1016/j.resourpol.2016. 11.0062016.

Söderholm, P., \& Svahn, N. (2015). Mining, regional development and benefit-sharing in developed countries. Resources Policy, 45, 78-91. https://doi.org/10.1016/j. resourpol.2015.03.003.

Stattman, S. L., \& Mol, A. P. J. (2014). Social sustainability of Brazilian biodiesel: The role of agricultural cooperatives. Geoforum, 54, 282-294. https://doi.org/10.1016/j. geoforum.2014.04.001.

Tschakert, P. (2009). Recognizing and nurturing artisanal mining as a viable livelihood". Resources Policy, 34(1-2), 24-31.

Vivoda, V., \& Kemp, D. (2019). The Extractive Industries and Society how do national mining industry associations compare on sustainable development. The Extractive Industries and Society, 6(1), 22-28. https://doi.org/10.1016/j.exis.2018.06.002.

Wagner, T. P., \& Raymond, T. (2015). Landfill mining: Case study of a successful metals recovery project. Waste Management, 45, 448-457. https:/ / doi.org/10.1016/j. wasman.2015.06.034

Weng, L., Endamana, D., Boedhihartono, A. K., Levang, P., Margules, C. R., \& Sayer, J. A.
(2015). Asian investment at artisanal and small-scale mines in rural Cameroon. Extractive Industries and Society, 2(1), 64-72. https:/ / doi.org/10.1016/j.exis.2014.07. 011.

Wessel, G. R. (2016). Beyond sustainability: A restorative approach for the mineral industry. The Geological Society of America, 2520, 45-55. https:/ / doi.org/10.1130/ 2016.2520(06).

World Commission on Environment and Development. WCED (1987). Our common future. Retrieved fromhttp://www.un-documents.net/ocf-01.htm.

Yakovleva, N., \& Vazquez-Brust, D. A. (2018). Multinational mining enterprises and artisanal small-scale miners: From confrontation to cooperation. Journal of World Business, 53(1), 52-62. https://doi.org/10.1016/j.jwb.2017.08.004.

Zamagni, S., \& Zamagni, V. (2010). Cooperative enterprise: Facing the challenge of globalization (1st ed.). Bologna: Edward Elgar Publishing.

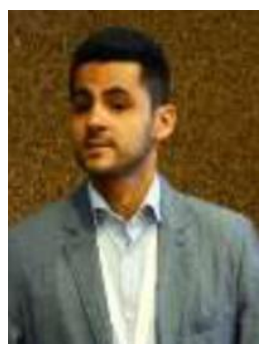

Wellington Alves Assistant Professor in the Polytechnic Institute of Viana do Castelo, is $\mathrm{PhD}$ in Industrial and Systems Engineering. His research interests are in the field of sustainability in the industrial sector, mainly applied to good practices for the mining sector. He has been workingat ALGORITMI Research Centre contributing to the research towards the implementation and improvement of sustainability issues concerning the Brazilian mining sector.http:// lattes.cnpq.br/7615736807813080

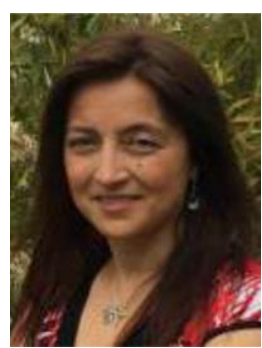

Paula Ferreira is Associate Professor in the Department of Production and Systems, School of Engineering, University of Minho. Her research interests are in the sustainability evaluation of industrial and energy systems, including economic, environmental and social dimensions. She relies on multidisciplinary scientific approaches including methods for social impact assessment and analysis of public perception towards clean technologies and services, environmental impact assessment and externalities valuation. She has vast experience on the coordination and participation in international and national projects and MSc and $\mathrm{PhD}$ supervision on energy, environment and project evaluation topics. Additional information in http://pessoais.

dps.uminho.pt/paulaf/

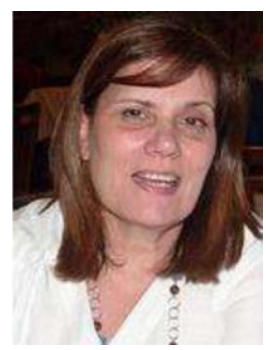

Madalena Araújo is Full Professor of Industrial and Technology Management in the Department of Production and Systems, School of Engineering, University of Minho. Her research interests are rooted in Decision Making under Risk and Uncertainty, mainly applied to management of industrial, technology and energy systems. Best Available Technologies for industrial sustainability, including economic, environmental and social dimensions, Project, Portfolio and Program Management, especially for University-Industry collaborations, are topics of research interest. She has vast experience on international and national projects and MSc and PhD supervision on project management, resource allocation, technology management, energy and environment topics. Additional information in http://pessoais.dps.uminho. $\mathrm{pt} / \mathrm{madalenaraujo/}$ 